\title{
Ka Bakau: Ekowisata Mangrove Berbasis Pengetahuan Lokal
}

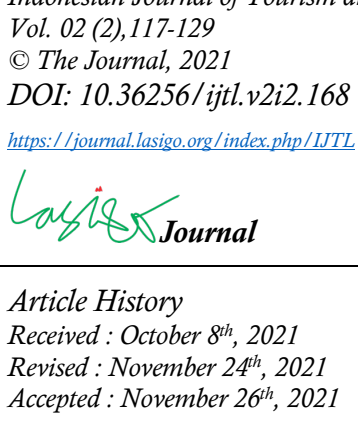

Accepted : November $26^{\text {th }}, 2021$

\section{Septian Yuda Pratama}

Jurusan Antopologi, FISIP, Universitas Andalas, Indonesia yudapratama541@gmail.com

\section{Rawa El Amady}

Program Pascasarjana Sosiologi, Universitas Riau, Indonesia mrawaelamady@gmail.com

\section{Achmad Hidir}

Jurusan Sosiologi, Universitas Riau, Indonesia

achmad.hidir@lecturer.unri.ac.id

\begin{abstract}
This study discussed mangrove ecotourism based on Sanak Sedagho, namely ecotourism management based on local wisdom. The management of sanak sedagho is novelty finding in the management of mangrove ecosystems. The mangrove ecotourism in Sungai Apit Sub-district is not active, while the Mangrove Sungai Bersejarah (MSB) Ecotourism still survives, it is still visited and as meeting place at the sub-district and district levels. This study is an ethnographic, where the researcher lived for two months in Sungai Ara Permai Village. The data were taken through library studies, internet, observation, participation observation, informal discussion and in-depth interviews. The main informants in this study are the initiators and managers of MSB Ecotourism and other informants who are community members and workers in MSB Ecotourism. This study found that the management of ecotourism based on local wisdom, in this case the sanak sedagho, is the key to the success of MSB Ecotourism being able survived even in the era of the covid 19 pandemic. This study contributes to the field of economic anthropology, especially in ecotourism management.
\end{abstract}

Keywords: Mangrove; Ecotourism; Sanak Sedagho; Local Wisdom.

\begin{abstract}
ABSTRAK
Studi ini membahas ekowisata mangrove yang berbasis sanak sedagho yaitu pengelolaan ekowisata berdasarkan kearifan lokal. Manajemen sanak sedagho ini merupakan temuan baru pada pengelolaan ekowisata mangrove. Sebagaimana diketahui bahwa semua ekowisata mangrove di Kecamatan Sungai Apit sudah tidak aktif, sementara Ekowisata Mangrove Sungai Bersejarah (MSB) masih bertahan hidup, tetap dikunjungi dan tetap menjadi tempat pertemuan tingkat kecamatan dan kabupaten. Studi ini merupakan studi etnografi, dimana peneliti berdiam selama dua bulan di Kampung Sungai Ara Permai. Data diambil melalui studi perpustakaan, internet, observasi, observasi terlibat, diskusi informasi dan wawancara mendalam. Adapun informan
\end{abstract}


utama dalam penelitian ini adalah penggagas dan pengelola Ekowisata MSB dan beberapa informan lain yang merupakan masyarakat serta pekerja di Ekowisata MSB. Studi ini menemukan bahwa pengelolaan ekowisata berbasis kearifan lokal dalam hal ini sanak sedagho menjadi kunci keberhasilan dari Ekowisata MSB bisa bertahan meskipun di era pandemi covid 19. Studi ini berkontribusi pada bidang ilmu antropologi ekonomi, terutama dalam manajemen ekowisata.

Kata Kunci: Mangrove; Ekowisata; Sanak Sedagho; Kearifan lokal.

\section{Pendahuluan}

Mangrove atau bahasa lokalnya bakau sedang menjadi perhatian pemerintah Indonesia dengan dimasukkannya mangrove ke Badan Restorasi Gambut (BRG) menjadi Badan Restorsi Gambut dan Mangrove (BRGM) berdasarkan Peraturan Presiden nomor 120 tahun 2020. Besarnya perhatian pemerintah pada mangrove ini tidak lepas dari fungsi yang melekat pada pohon mangrove yaitu sebagai penyangga abrasi, penjaga produksi ikan dan penyedia emisi karbon terbesar (Windarni, Setiawan, \& Rusita, 2018) dan yang sedang digalakkan sekarang adalah mangrove sebagai ekowisata. Secara nasional terdapat 183 agrowisata mangrove yang ada di setiap provinsi (Rahmanto, 2020).

Ekowisata merupakan sub-kategori dari pariwisata berkelanjutan. Oleh karena itu, ekowisata merupakan perjalanan dan kunjungan wisata yang bertanggung jawab terhadap keberlangsungan alam dan lingkungan destinasinya (Firdaus \& Tutri, 2017). Ekowisata mangrove sebagaimana disampaikan Kordi (2012) mengedepankan pemanfataan ekosistem mangrove untuk konservasi pantai dan ekosistem mangrove. Konservasi pantai ini berdampak positif dalam melawan abrasi pantai, menghasilkan karbon yang lebih tinggi dari pohon lainnya (Sumar, 2021). Pemanfaatan ekosistem mangrove sebagai ekowisata juga berperan penting untuk menjaga mangrove dari penebangan liar.

Ekowisata mangrove merupakan kegiatan jasa kehutanan dengan tujuan konservasi (Mukhlisi, 2017). Konservasi dalam arti menjaga yang sudah ada, memperbaiki yang sudah rusak dan menanamkan nilai-nilai kepada pengunjung dan masyarakat tentang pentingnya mangrove bagi kehidupan masyarakat. Oleh karenanya, kegiatan wisata di kawasan wisata mangrove mengharuskan agar semua kegiatan wisata memenuhi standar konservasi dengan tetap menjaga kekhasan pada kawasan mangrove masing-masing. Tidak mudah mengatur pengunjung untuk berperilaku sesuai standar konservasi. Jika penerapan standar konservasi diterapkan secara tidak tepat bisa menyebabkan tempat wisatanya sepi pengunjung.

Beberapa studi tentang pengelolaan ekowisata mangrove lebih fokus pada ekologi dan ekonomi (Liap, Masyhudzulhak, \& Saluy, 2019), begitu juga Nugroho berfokus bisnis, modal sosial dan modal alam, Tuwo berfokus pada ekonomi dan kelembagaan masyarakat, juga Kate berbasis ekolog, sosial budaya dan ekonomi (Wati, 2017). Sedangkan Umam et al (2015) memperkenalkan manajemen berbasis promosi dan publikasi. Studi-studi terdahulu tersebut fokus kepada penerapan manajemen pada pengelolaan ekowisata mangrove. Nugroho dan Kate meletakan aspek modal sosial dan sosial budaya dalam pengelolaan ekowisata mangrove tetapi belum meletakan kearifan lokal sebagai dasar pengelolaan ekowisata mangrove. Ekowista Magrove Sungai Bersejarah (MSB) meletakan kearifan lokal sebagai pendekatan utama dalam pengelolaanya. Pendekatan pengelolaan Ekowsia MSB ini merupakan pendekatan yang baru berbasis pada kearifan lokal yang sekaligus sebagai modal sosial.

Ekowisata Mangrove Sungai Bersejarah (MSB) di Kampung Kayu Ara Permai Kecamatan Kayu Apit Kabupaten Siak Riau merupakan salah satu dari 183 ekowisata mangrove yang ada di Indonesia. Berkat Ekowisata Mangrove Sungai Bersejarah yang berdiri pada tahun 2018 dan 
resmi dibuka tahun 2019 menghantarkan Kampung Kayu Ara Permai menjadi salah satu kampung wisata di Kabupaten Siak. Ekowisata MSB juga sudah menjadi objek wisata masyarakat dari berbagai daerah di Riau bahkan dari luar negeri. Ekowisata lain seperti Ekowisata Mengkapan, Ekowisata Tanjung Kurai dan Ekowisata Kampung Kayu Ara di Kecamatan Sungai Apit tidak beroperasi sama sekali selama covid 19. Namun Ekowisata MSB tetap dikunjungi wisatawan dan menjadi tempat rapat pemerintah kecamatan dan pemerintah kabupaten Siak meskipun kegiatan wisata ditutup karena Covid 19. Menurut Budi bahwa Ekowisata MSB ramai dikunjungai oleh wisatawan yang berasal dari Dumai, Kota Siak dan desa-desa tetangga. Penghasilan pada hari libur bisa mencapai Rp.1.000.000,- sampai Rp.3.000.000,-. sedangkan pada hari biasa bisa mencapai Rp.300.000.-/hari (Budi, Wawancara, 9/9/2021).

Ekowisata MSB juga mendapat perhatian perusahaan multi nasional Energi Mega Persada (EMP) Malacca Street. EMP membuat program pembibitan, edukasi mangrove kepada pengunjung terutama anak-anak sekolah dan membangun mushollah di dalam area wisata dan pelatihan pengelolaan wista desa ke Pokdarwis (Kelompok Sadar Wisata). Begitu juga perusahaan pulp and paper PT RAPP, PT PLN, LSM Elang, KAR (Kelompok Advokasi Riau) dan Universitas Riau juga pernah melaksanakan program pendampingan di ekowisata MSB, melakukan penanaman, pelatihan dan penguatan kelompok Konservasi Mangrove pernah dilakukan di sini.

Pada saat pandemik covid 19, pemerintah melarang membuka Ekowisata MSB, namun tetap memberi kesempatan orang - perorang mengunjungi tujuan ekowisata MSB secara gratis. Pada saat pandemi ini MSB tetap dijaga oleh satu orang petugas untuk mengawasi aktivitas pengunjung, sedangkan sebelumnya dijaga oleh 3 sampai 4 orang petugas. Kegiatan di kawasan wisata pada saat pandemi yaitu perbaikan dan melengkapi fasilitas publik berupa tempat pertemuan, membangun masjid dan memperbaiki jalan serta merancang rencana pengembangan MSB untuk kepentingan pasca covid 19. Setiap hari selalu ada pengunjung dari warga Kampung Kayu Ara Permai, kampung tetangga, kabupaten bahkan dari Pekanbaru dengan jumlah yang terbatas. Anak-anak muda memanfaatkan kesempatan bercengkrama dengan pasangannya di Ekowista MSB secara gratis. Pertemuan-pertemuan kampung, antar kampung, dan pertemuan kabupatenpun tetap dilaksanakan di ekowisata MSB ini. Kemampuan Ekowisata MSB bertahan menjaga asa bahwa ekowisata MSB tetap ada dan akan segera dibuka jika pemerintah sudah mengizinkan dibuka, merupakan daya tarik sendiri untuk menulis tema ini.

Fenomena ekowisata MSB ini merupakan fenomena yang sangat menarik walaupun jauh dari kota tetapi mampu bertahan meski pada situasi pandemi. Pembangunan dan pengembangan tetap dilaksanakan dari biaya hasil sebelum pandemi covid 19, sehingga ekowisata tetap dinanti oleh pengunjung setelah larangan membuka tempat wisata dicabut. Ekowisata MSB menjadi spesifik dan lebih menarik karena berbagai ekowisata mangrove di Kecamatan Sungai Apit menghadapi masalah untuk tetap bertahan, sedangkan Ekowisata MSB baik-baik saja. Atas dasar itu, maka penelitian ini memfokuskan pada karakter spesifik yang dimiliki oleh Ekowisata MSB yang berbeda dengan ekowisata lain di Kecamatan Sungai Apit.

Selama hampir dua bulan observasi di Ekowisata MSB, pengurusnya memfokuskan pada generasi muda dan pengetahuan lokal dalam mengelola ekowisata ini. Keterlibatan penduduk lokal untuk menjaga ekowisata ini berpengaruh besar terhadap bertahannya ekowisata ini, walaupun secara tidak sadar kegiatan masyarakat lokal seperti memancing, mencari ikan ataupun hanya sekedar mampir sebentar sambil membawa keluarga bertamasya ke tempat ekowisata merupakan salah satu yang dapat dijadikan alasan Ekowisata MSB ini tetap bertahan. Pendekatan pengelolaan di Ekowisata MSB yang spesifik ini merupakan tujuan dari penelitian ini, untuk mengetahuinya lebih mendalam dan menjadi pembelajaran di tempat lain. 


\section{Tinjauan Pustaka}

Ekowisata merupakan kegiatan wisata yang berbasis alam sebagaimana pendapat Ceballos \& Laurin (1995) bahwa ekowisata adalah wisata berbasis alam, mempromosikan konservasi, dan bermanfaat secara sosial dan ekonomi bagi penduduk setempat. Mangrove yang masih alami dikelola menjadi wisata agar lebih alami dan terjaga sehingga mendapatkan manfaat ekonomi bagi masyarakat (Winarno, 2017). Pendapat Ceballlos, Laurain dan Winarno tersebut baru bisa terwujud jika dalam pelaksanaannya memperhatikan dan melibatkan aspek lokal terutama pengetahuan lokal yang dalam pemanfaatan mangrove dan budaya lokal serta tradisi-tradisi lokal. Tuwo (2011) menyampaikan bahwa pengembangan ekowisata adalah salah satu alternatif pembangunan yang dapat mengatasi masalah desakan kebutuhan hidup yang semakin lama semakin tinggi. Secara umum daya tarik wisata dapat dikelompokkan menjadi tiga, yaitu segala sesuatu yang berasal dari alam, segala sesuatu yang bersumber dari budaya, dan segala sesuatu hasil buatan manusia (Prasiasa, 2011).

Kearifan lokal berwujud pada budaya lokal, budaya dalam konteks yang lebih luas yaitu segala sesuatu yang disepakati sebagai nilai bersama yang dilaksanakan secara bersama. Sebagaimana Sibarani (2015) menyimpulkan bahwa kearifan lokal adalah pengetahuan asli (indigineous knowledge) atau kecerdasan lokal (local genious) suatu masyarakat yang berasal dari nilai luhur tradisi budaya untuk mengatur tatanan kehidupan masyarakat dalam rangka mencapai kemajuan komunitas baik dalam penciptaan kedamaian maupun peningkatan kesejahteraan masyarakat.

Adapun peran dari nilai-nilai kearifan lokal dan fungsinya menurut Sartini adalah untuk konservasi dan pelestarian sumberdaya alam, pengembangan sumberdaya manusia, pengembangan kebudayaan dan ilmu pengetahuan, sumber petuah dan pantangan, sebagai sarana membentuk bangunan integrasi komunal, sebagai landasan etika dan moral, terakhir adalah sebagai fungsi politik (Basyari, 2014). Beberapa fungsi di atas dapat menjadikan kearifan lokal sebagai suatu kebutuhan bagi masyarakat setempat. Dalam prakteknya ada cukup banyak pengetahuan lokal yang berhubungan langsung dengan mangrove yang masih ada sampai sekarang. Sejalan dengan pendapat Bakar dalam Prabandari (2018) kearifan lokal diperlukan dalam pemaknaan lain sebagai simbol semangat dalam pembangunan.

Maunati (2001) menyampaikan bahwah hubungan antara pariwisata dan kebudayaan ini menghasilkan implikasi yang baik terhadap ekonomi dan sosial, dimana bidang ekonomi kebudayaan dimaksudkan dalam bentuk pertunjukan, pameran, demonstrasi, pesta (festival) yang memberikan kesempatan bekerja, berkarya bagi masyarkat lokal. Menurut Basyari (2014) kearifan lokal sebagai suatu kebenaran yang telah mentradisi atau ajeg dalam suatu daerah. Kedudukan nilai-nilai budaya dan sosial merupakan modal sosial (social capital) untuk pariwisata.

Merujuk ke pendapat Rahyono (2009) bahwa kearifan lokal merupakan kecerdasan manusia yang dimiliki oleh kelompok komunitas tertentu yang diperoleh dari pengalaman sehari-harinya. Pendapat ini menghantar ke suatu pemahaman bahwa kearifan lokal bukanlah sesuatu yang harus sudah lama tetapi juga sesuatu yang muncul akibat suatu kondisi tertentu yang baru terjadi. Kesadaran pemuda bahwa mangrove merupakan solusi dan perlu dijaga melalui ekowisata dan kemudian menjadi satu keyakinan dan kebenaran dalam berprilaku masyarakat juga merupakan salah bentuk dari kearifan lokal. Pengelolaan mangrove yang berbasis nilai lokal juga merupakan salah satu bentuk dari kearifan lokal. Hal itulah yang dipraktekan pada pengelolaan Ekowisata MSB.

\section{Metode Penelitian}

Penelitian ini dilakukan di Kampung Kayu Ara Permai, Kecamatan Sungai Apit, Kabupaten Siak, Riau. Lokasi ini dipilih karena terdapat ekowisata MSB yang masih bertahan dan sudah 
menjadi pusat dari kegiatan ekowisata maupun kegiatan-kegiatan yang lain seperti pelatihan, pengabdian dosen, ataupun acara resmi pemerintah yang lain se-Kecamatan Sungai Apit.

Penelitian ini bersifat deskriptif yaitu penelitian yang bertujuan untuk mendeskripsikan atau menjabarkan realitas sosial yang ada dalam masyarakat yang berkaitan dengan tempat ekowisata, baik itu hubungan antara ekowisata dan masyarakat lokal maupun kontribusi tentang ekowisata pada desa dan masyarakat. Metode pada penelitian ini adalah etnografi, dimana menelaah kebudayaan masyarakat, menyajikan fakta kultural dari hasil wawancara, observasi dan dokumentasi. Metode ini diharapkan dapat memberikan gambaran tentang hubungan masyarakat dengan daerah ekowisata yang nantinya dapat dijadikan pedoman dalam penulisan. Etnografi sebagai metode tertua dalam riset kualitatif sangat penting dalam penelitian sosial dan budaya, dimana karakteristiknya yaitu: 1). Menggali dan meneliti fenomena sosial budaya, 2). Data tidak terstruktur, 3). Kasus atau stempel sedikit, 4). Melakukan analisis data dan interpretasi data tentang arti dari tindakan manusia (human action) menurut Atkinson dan Hammersley, 1994 dalam Setyowati (2006).

Alasan menggunakan metode ini karena metode ini terdapat pendekatan emosi masyarakat, cara pandang maupun cara hidup yang nantinya akan mengungkap bagaimana kehidupan masyarakat daerah pesisir. Fokus utama etnografi adalah mengumpulkan data dengan observasi dan wawancara mendalam, deskripsi yang tebal dan mendalam secara ilmiah, bekerja bersama informan kunci dan dimensi 'emic/etic' (Setyowati, 2006). Pada dasarnya, perhatian utama penelitian etnografi adalah tentang the way of life suatu masyarakat Spradley (2007) menambahkan bukan hanya sekedar mempelajari masyarakat tapi belajar dari masyarakat. Penelitan dilakukan secara bertahap, tahap pertama studi perpustakaan baik sebelum turun lapanan, sedang dilapangan dan setelah selesai studi lapangan; Kedua, melakukan observasi khususnya di Ekowisata MSB, dilanjutkan observasi partisipatif telibat dengan kegiataan di Ekowisata MSB; Ketiga, penetapan tema riset sesuai dengan hasil analisas dari data sekunder dan observasi; Keempat, melakukan wawancara mendalam terhadap informan terpilih. Wawancara ini akan memperdalam dari hasil observasi dan observasi terlibat. Variabel utama yang dibahas kepada informan adalah manajemen pengetahuan lokal dalam pengelolaan Ekowisata MSB.

Pada penelitian kualitatif terdapat dua jenis data, pertama yaitu data primer, adalah data yang diambil langsung dari informan penelitian, kedua data sekunder adalah sumber yang tidak langsung berasal dari dokumen, arsip maupun buku (Sugiyono, 2012). Data primer dikumpul dengan observasi, observasi partisipasi dan wawancara mendalam. Penelitian dilakukan dengan jangka waktu penelitian 2 bulan yaitu dari tanggal 16 Agustus 2021 - 16 Oktober 2021. Observasi atau pengamatan dilakukan atas dasar tujuan dan pertanyaan penelitian. Observasi dilakukan langsung dilapangan pada saat penelitian. Peneliti mengobservasi seluruh kampung dan juga seluruh masyarakat yang berada di desa. Sedangkan data sekunder dikumpulkan melalui perpustakaan dan internet.

Peneliti membangun kedekatan dengan Penghulu Kampung Kayu Ara Permai dan lama berdiam dirumah beliau, dan juga membangun relasi dengan para pemuda Kayu Ara Permai, ikut dalam kegiatan seperti acara perkawinan (rewang), ikut dalam kegiatan reses DPRD bersama para pemuda dan juga penghulu, ikut dalam kegiatan olahraga maupun kesenian dan lain-lain. Peneliti melakukan upaya ini supaya masyarakat dapat menerima dan percaya bahwa peneliti sudah diakui dan dianggap oleh masyarakat Kampung Kayu Ara Permai. Modal sosial yang telah dibangun peneliti tersebut memberi akses bagi peneliti pada ruang-ruang yang tadinya belum tentu bisa diikuti.

Wawancara mendalam bertujuan untuk menemukan arti budaya yang terjadi pada group social, terutama interaksi, konteks sosial dan konstruksi sosial dari pengetahuan pendapat dari Lowenberg dalam Setyowati (2006). Ada tiga unsur penting dalam pengajuan pertanyaan 
wawancara yakni tujuan yang eksplisit, penjelasan, dan pertanyaan yang bersifat etnografis (Kamarusdiana, 2019). Pada dasarnya etnografi adalah menjalani proses dimana sang peneliti dapat membangun hubungan baik dengan informan (rapport) agar mendapatkan informasi dari para informan. Peneliti menggunakan rekaman agar informasi yang didapat pada saat wawancara didapatkan semua dan dapat membantu peneliti dalam menganalisa.

\section{Hasil dan Pembahasan}

\section{1. Gambaran Lokasi Penelitian}

Kampung Kayu Ara Permai terletak di Kecamatan Sungai Apit, Kabupaten Siak Provinsi Riau, berada dibibir Selat Malaka namun lebih dikenal selat Lalang. Secara historis, Kampung Kayu Ara Permai merupakan kampung baru yang semula merupakan pemekaran dari Kampung Sungai Kayu Ara berdasarkan Perda Kabupaten Siak No 6 tahun 2009. Nama Kampung Sungai Kayu Ara diambil dari nama sungai yang digunakan sebagai sarana transportasi, di sungai tersebut terdapat satu pohon kayu ara besar yang berdiri di atas sungai dengan akarnya terdapat di masing-masing pinggir sungai, maka disebutlah sungai tersebut sungai kayu ara, lalu ketika pinggiran sungai tersebut berubah menjadi desa maka dinamai dengan Desa Kayu Ara.

Gambar 1. Peta Lokasi Penelitian

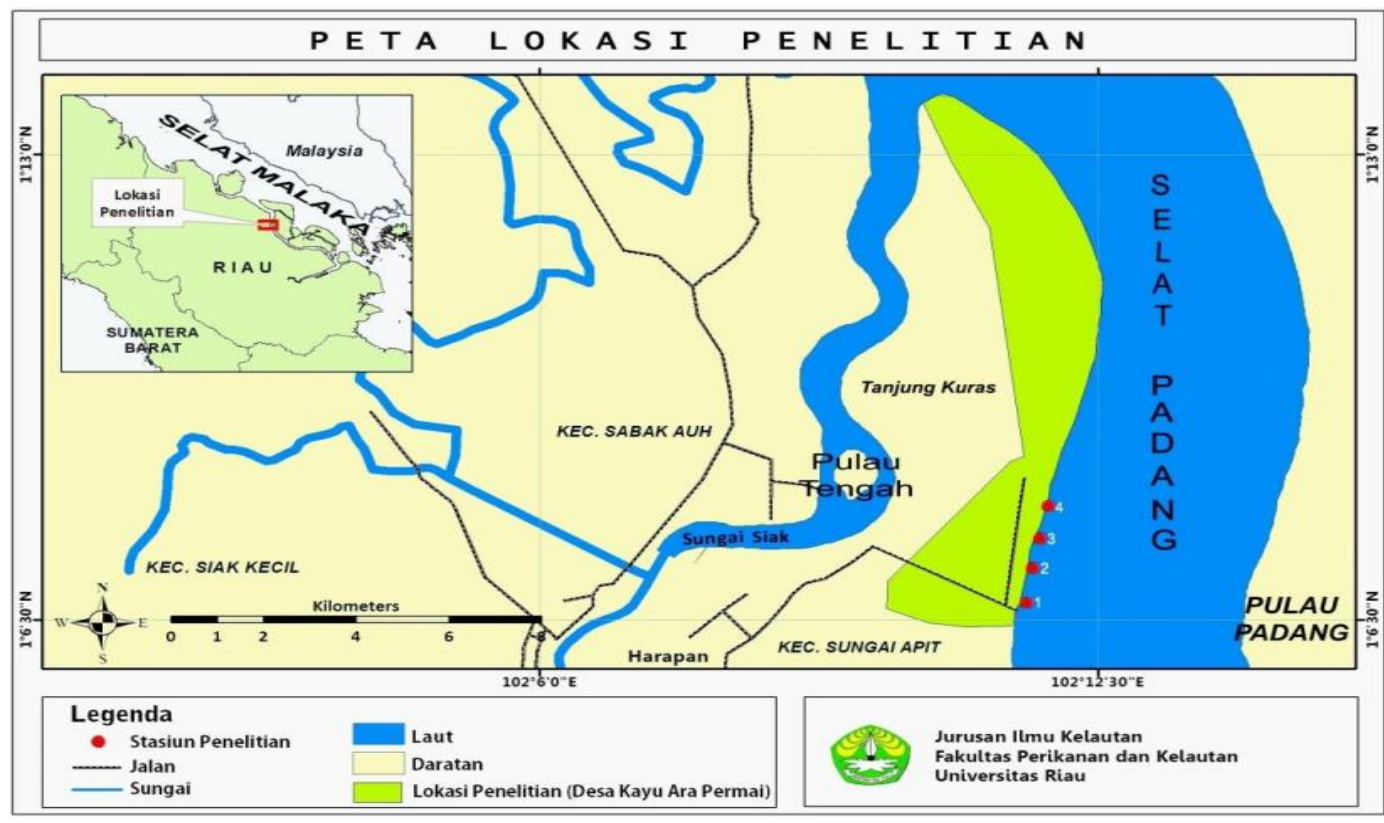

Sumber : Syahrian \& Zulkifli (2018)

Penduduk Kampung Kayu Ara Permai pada awal pembentukan Kampung Kayu Ara ada beberapa yang berasal dari Kampung Lalang dan Sungai Apit, sebab Kampung Kayu Ara berada ditengah-tengah antara Kampung Lalang dan Sungai Apit. Warga Kampung Kayu Ara Permai merupakan masyarakat yang terbuka yang sudah saling berinteraksi dengan berbagai suku bangsa, terdapat beberapa suku bangsa yaitu suku Melayu, Flores, Minang, Jawa, Akit, dan lainnya.

Menurut data kampung bulan Juni tahun 2020 jumlah penduduk Kampung Kayu Ara Permai pada bulan Juni tahun 2020 sebanyak 294 KK, yang terdiri dari 553 jiwa laki-laki dan 480 jiwa perempuan dengan total 1033 jiwa. Mayoritas suku melayu sekitar 80\% selebihnya dari etnis Jawa, Minang, Cina, Bugis dan, Batak, dan Akit yang tersebar di 3 Dusun, 6 Rukun Keluarga (RK), dan 12 Rukun Tetangga (RT). Kampung Kayu Ara Permai juga memiliki hutan mangrove yang dijadikan kawasan ekowisata. 
Berdasarkan pendidikan, terdapat 802 orang lulus pendidikan umum, dengan rincian 26 orang sarjana, 32 orang tamatan D3, 227 orang tamatan SMA, 137 orang tamatan SMP, 340 orang tamatan SD, dan 40 orang tamatan Taman Kanak-kanak.

Tabel 1. Masyarakat Kampung Ara berdasarkan pekerjaan

\begin{tabular}{|c|l|c|}
\hline Nomor & Pekerjaan & Jumlah \\
\hline 1 & Karyawan & 46 orang \\
\hline 2 & Wiraswasta/pedagang & 98 orang \\
\hline 3 & Buruh Tani dan Petani & 61 orang \\
\hline 4 & Nelayan & 18 orang \\
\hline 5 & Peternak & 7 orang \\
\hline 6 & Jasa & 10 orang \\
\hline 7 & Pekerja Seni, Pengrajin, Pensiunan & 4 orang \\
\hline 8 & Lainnya & 552 orang \\
\hline 9 & Tidak bekerja/ pengangguran & 237 orang \\
\hline
\end{tabular}

Sumber: Diolah dari data lapangan (2021)

\section{2. Ekowisata MBS: Sejarah dan Pembentukannya}

Syahrian \& Zulkifli (2018) melaporkan bahwa di Kampung Kayu Ara Permai mempunyai delapan spesies yaitu A. alba, B. parviflora, B. gymnorizha, B. sexangula, $R$. apiculata, $S$. alba, $S$. caseolaris dan $X$. granatum. Posisi mangrove juga tidak jauh dari jalan raya sehingga dengan mudah dapat dijangkau oleh wisatawan, dengan view laut Selat Malaka/Lalang, sehingga bisa memandang ke laut dengan leluasa, pengeboran minyak lepas pantai dan kegiatan nelayan. Bahasa lokal mangrove adalah bakau, sehingga dahulunya masyarakat jika akan pergi ke mangrove menyebutnya dengan "ka bakau" yang berarti ke bakau atau pergi ke tempat bakau. Penamaan mangrove sendiri dikarenakan pelatihan dan banyaknya informasi yang di dapat dari luar sehingga sebutan "ka bakau" tadi sudah jarang digunakan bahkan orang-orang tua yang dulunya memakai istilah lokal "ka bakau" juga sudah menggunakan mangrove.

Sebelum dibentuk ekowisata, kawasan Ekowisata MSB merupakan hutan mangrove yang digunakan sebagai lahan berladang dan menanam padi, hingga tahun 1965 masih dijumpai sawah dan ladang masyarakat di kawasan Ekowisata MSB. Sejak tahun 1965 selalu terjadi abrasi di kawasan bibir pantai, sawah, dan ladang masyarakat sudah menjadi laut sehingga yang tersisa hanya kawasan Ekowisata MBS ini saja. Ombak laut yang membawa air asin semakin hari semakin kuat menerpa bibir pantai, sehingga pantai menjadi kandas karena abrasi. Jarak antara kampung dengan Pulau Seberang atau Pulau Padang yang dahulunya tidak jauh sekarang sudah sangat jauh, orang-orang yang dahulunya hanya memakai sampan kecil untuk menuju pulau seberang, sekarang harus menggunakan pompong (perahu bermesin). Pengikisan air laut itu terjadi sampai sekarang bahkan walaupun sekarang sudah ada tempat ekowisata, pohon-pohon yang diujung dekat bibir pantaipun sudah ada beberapa yang tumbang akibat abrasi yang terjadi. Merespon tingginya abrasi tersebut maka di tahun 2020 dilakukan penanaman mangrove oleh pihak Balai Besar Konservasi Sumber Daya Alam (BBKSDA) Riau dengan melibatkan para masyarakat dan pemuda sebanyak 2000 pohon jenis bakau di kawasan bibir pantai sekitar 5 hektar.

Pada awal berdirinya yaitu bulan Maret tahun 2016 sekelompok pemuda desa yang terdiri dari 5 orang melakukan upaya penanaman mangrove sebanyak 100 batang dengan niat untuk menjadikan hutan mangrove ini sebagai tempat wisata. Ide ini dilanjutkan oleh kelompok pemuda tadi dengan membentuk organisasi Konservasi Laskar Mandiri. Adapun struktur organisasi adalah Oyon (Ketua), Ajay (Bendahara), Bang Ijal (Sekretaris), Bang Adi (Koordinator Lapangan).

Kelompok inilah yang mengelola mangrove hingga saat ini, kelompok ini terdiri dari pengurus inti dan anggota yang dimana anggota tersebut adalah pemuda desa yang ikut 
bergabung dalam kegiatan mangrove. Organisasi Konservasi Laskar Mandiri yang sudah terbentuk pada awal tahun 2018 ini yang beranggotakan seluruh anak muda lokal yang ada dan juga yang termasuk dalam karang taruna, dengan kepengurusan inti yang aktif berjumlah 15 orang. Di dalam kepengurusan organisasi konservasi, para pemuda yang terlibat tidak terikat oleh apapun sehingga para anggota bebas ikut berpartisipasi atau tidak, tapi pada setiap acara seperti rapat, pertemuan ataupun diskusi para pengurus inti tetap melibatkan dan mengundang para pemuda baik itu tergabung dalam pengurus ataupun tidak tergabung.

Gambar 2. Kawasan Wisata Mangrove MSB
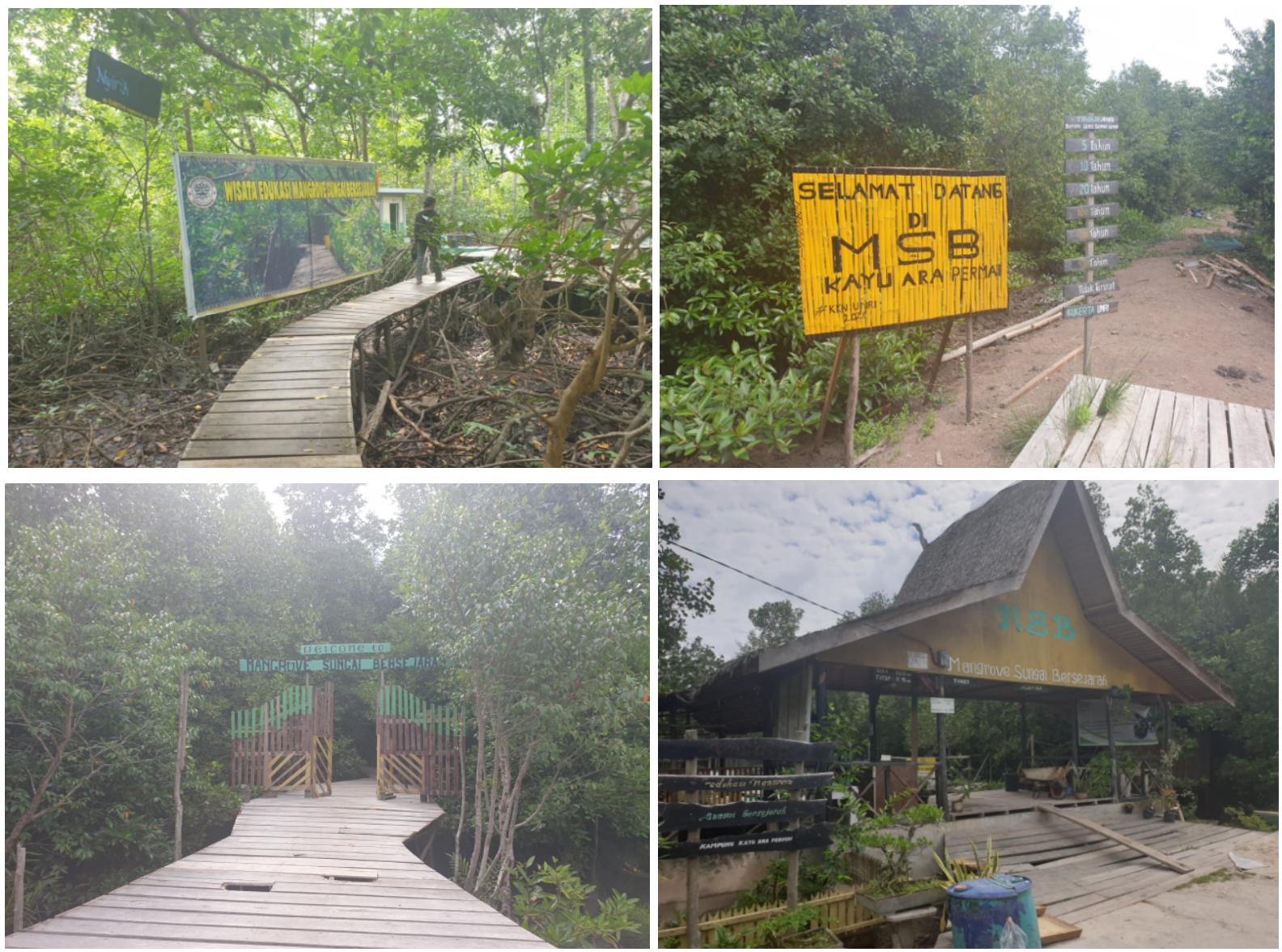

Sumber: Foto ketua $R W$, (2021)

Organisasi KLM ini yang mempunyai ide hingga lahirnya ekowisata MSB secara swadaya mencari kayu dan bambu di hutan untuk membangun jalur atau trek lintasan akses pengunjungan dari pintu masuk hingga ke bibir pantai selat Lalang. Pada akhir tahun 2017 KLM berhasil membangun trek sepanjang 30 meter, kemudian di tahun 2019 Penghulu Kampuang Kayu Ara Permai membiayai trek sepanjang 250 meter. Tahun 2019 KLM menambah trek hingga mencapai 450 meter, 5 unit pendopo dan 2 unit toilet dan untuk saat ini juga telah dibangun mushollah beserta aula yang cukup besar. Pembangunan trek dan fasilitas publik serta informasi di media sosial MSB mendapat banyak pengunjung yang datang dari kampung sekitar dan bahkan ada juga yang dari daerah lain seperti Dumai, Rohil, Rohul, Aceh dan mancanegara seperti Australia, Korea dan Singapura. Pendapatan ekowisata mangrove dapat menghasilkan 1 3 juta perhari pada hari libur nasional atau bahkan hari libur akhir pekan. Sekretaris MSB Jefrizal (Wawancara, 13 September 2021) menyampaikan mengapa ekowisata mangrove ini diberi nama Mangrove Sungai Bersejarah (MSB) karena di kampung terdapat sungai yang diberi nama Sungai 
Bersejarah. Menurut cerita sungai inilah yang menjadi awal berdirinya Kampung Kayu Ara Permai atau yang dulunya Kampung Sungai Kayu Ara.

Kegiatan wisata yang diberikan pada tempat wisata ini berupa rute perjalanan wisata mangrove yang cukup panjang sekitar kurang lebih 200 meter dengan pemandangan hutan mangrove yang masih sangat asri dan banyak pohon rindang. Masih banyaknya satwa yang bergantung hidup di sini seperti beberapa spesies monyet. spesies burung, ikan, udang dan serangga.

Perjalanan yang cukup panjang membuat pengunjung kelelahan sehingga ada beberapa masyarakat lokal yang ikut menjual dagangan sehingga pengunjung tidak perlu lagi membeli makanan dan minuman dari luar. Tidak hanya itu, didalam ekowisata ini juga terdapat fasilitas berupa musholla, wc, aula dan pondok-pondok agar pengunjung betah berada di dalam kawasan ekowisata. Di dalam perjalanan masuk ke dalam ekowisata yang cukup panjang pondok-pondok kecil tadi ada disebelah kiri atau kanan sehingga bagi para pengunjung yang ingin istirahat tidak mesti harus menuju ujung dari tempat ekowisata tapi disetiap perjalannya ekowisata ini menyediakan beberapa pondok. Bagi para keluarga yang ingin berkunjung tempat wisata juga menyediakan aula yang berada di tengah tempat wisata dan pondok yang cukup besar yang berada di bagian ujung. Para keluarga yang berkunjung membawa bekal dari rumah untuk dimakan di daerah ekowisata.

\section{3. Manajemen Sanak Sedagho}

Ekowisata MSB menumbuhkan satu prilaku dan nilai bahwa menjaga mangrove adalah satu keharusan. Mengoptimalkan mangrove melalui ekowisata sebagaimana pada Ekowisata MSB terbukti bisa mendatangkan penghasilan bagi generasi muda sekaligus memberi ruang bagi generasi muda untuk berkreativitas di Kawasan Ekowisata MSB. Selain itu, konservasi mangrove akan memberi manfaat juga kepada nelayan karena dengan mangrove akan menjadi tempat berkembangnya ikan, udang dan biotik lainnya sehingga nelayan bisa dengan mudah mendapatkan ikan, udang, kepiting dan lain-lainnya. Selaras dengan pendapat Syahrera \& Purnama (2016) hutan mangrove juga digunakan sebagai tempat tinggal, tempat berlindung dan tempat mencari makan bagi biota perairan salah satunya ikan.

Pemuda Kampung Sungai Ara Permai yang menginisiasi pembentukan Ekowista MSB dalam pengelolaan Ekowisata MSB merangkul semua anak muda yang ada di kampung melalui pengelolaan berbasis pada pengetahuan (kearifan) lokal. Nilai kearifan lokal yang tonjolkan adalah semua warga yang berdiam di kampung Sungai Kayu Ara Permai adalah sebuah keluarga besar. Ekowisata MSB merupakan milik seluruh warga kampung, sehingga semua peluang yang tersedia di ara Ekowisata MSB bisa diakses untuk usaha, mengelola dan terlibat pada kegiatan di Ekowisata MSB.

Praktek penerapan kearifan lokal tersebut dikenal dengan sanak sedagho, yaitu sebuah modal sosial yang dimiliki oleh warga kampuang, bahwa seluruh warga kampung adalah bersaudara tidak memandang suku bangsa. Sanak sedagho merupa simbol kepercayaan dan kesetraan sesama warga kampung, sehingga setiap orang mempunyai kesempatan dan hak yang sama untuk mendapatkan kesempatan terlibat di Ekowista MSB. Pokdarwis lebih beperan sebagai perencana dan pengatur tetapi dalam terlibat di aktivitas wisata semuanya diberi kecepatan selagi masih tersedia peluang tersebut. Semua warga desa merupakan bagian dari keluarga sehingga setiap orang dipercayai sebagai keluarga sendiri.

Sanak sedagho adalah nilai pengetahuan lokal yang meletakan semua warga kampung sebagai keluarga, sanak keluarga tanpa memandang agama dan etnis, asli dan pendatang. Ekowisata MSB memberi kesempatan kepada semua orang dari Kampung Kayu Ara Permai untuk memanfaatkan wisata ini sebagai alternatif tambahan pendapatan, baik bekerja harian di ekowisata, berjualan maupun menyediakan jasa bagi kelancaran Ekowisata MSB. Pekerja di 
Ekowisata MSB merupakan sukarelawan yang dibayar dengan sistem bagi hasil. Siapa yang datang lebih dahulu dialah yang mendapat kesempatan menjadi sukarelawan untuk menjual tiket masuk, mendampingi pengunjung, membantu pengunjung, mengatur parkir dan berbagai kegiatan lain yang ada di Ekowisata MSB. Setiap pendapatan harian diserahkan kepada Pokdarwis pada saat Ekowista MSB tutup. Semua pendapatan tersebut dibagi 3: 1, 3 untuk pengembangan Ekowisata MSB dan 1 untuk sukarelawan. Basis nilai keparcayaan sanak sedagho ini memperkuat solidaritas sesama anak muda di Kampung Kayu Ara Permai dan menjaga kelangsungan Ekowisata MSB.

Menurut Ketua Pokdarwis Sabarion (Wawancara, 20 Agustus 2021) pengelolaan ekowisata ini diisi oleh anak-anak muda, ada yang mengantarkan para pengunjung sampai ke dalam, ada yang menjaga parkir, ada yang menjaga karcis, mengelola sampah, menghibur pengunjung dengan bernyanyi, berdagang dan membantu pengunjung. Para pemuda diberi uang saku setiap hari setiap terlibat pada kegiatan ekowisata. Untung dalam sehari juga akan dikembalikan ke ekowisata untuk menambah uang kas Pokdarwis nantinya dapat dijadikan sebagai salah satu modal untuk membuat even. Anak-anak muda juga diberi kesempatan memanfaatkan sampah plastik untuk kreasi tempat pengunjung berfoto dan bagi siapa karyanya mendapatkan banyak pengunjung untuk foto akan diberi hadiah.

Selain itu pemuda - pemudi menjadikan tempat wisata sebagai tempat untuk berlatih kesenian dan tempat untuk berkumpul para pemuda untuk berdiskusi. Berlatih kesenian melayu seperti memainkan gambus dan berlatih tari-tarian sangat sering dilakukan oleh para anak muda lokal yang juga tergabung dalam beberapa sanggar. Biasanya para pemuda berlatih di aula yang ada di dalam lokasi ekowisata. Walaupun hanya sekedar latihan biasa namun dapat dijadikan daya tarik bagi pengunjung yang datang. Terutama setidaknya pengunjung mendapatkan hal baru yang menarik di dalam kegiatan ekowisata yang menampilkan kearifan lokal sebagai produk budaya lokal dan menambah daya tarik bagi pengunjung yang datang.

\section{4. Memperkuat Kearifan Lokal}

Pengelolaan Ekowisata MSB yang berbasis pada kearifan lokal mempunyai pengaruh positif, meliputi koservasi mangrove, memperkuat modal sosial di Kampung Kayu Ara Permai. Hubungan antara gerasi muda semakin erat dan sesama mereka saling mempercayai. Kearifan lokal dalam pengelolaan Ekowisata MSB melalui sanak sedagho perlu diperkuat dengan mengembangkan kearifan lokal yang mempunyai hubungan dengan mangrove. Kearifan lokal yang berhubungan dengan mangrove merujuk pada aktivitas nelayan yang selama ini ada teta dilaksanakan di Kampung Kayu Ara Permai.

Kehadiran Ekowisata MSB ini akan mempunyai manfaat yang lebih luas ke seluruh masyarakat jika kegiatan di Ekowisata MSB melibatkan kegiatan sehari-hari masyarakat secara langsung. Melalui pengembangan kegiatan wisara maka akan membentuk kemandirian masyarakat pesisir untuk bertahan dalam situasi apapun, trutama dapat memenuhi kebutuhan keluarga ataupun kelompok. Kemandirian lokal tadi dapat berjalan beriringan dengan kearifan lokal yang sudah ada dan dipelajari seiring dengan perkembangan zaman sampai saat ini. Ekowisata MSB bisa menjadi alternatif sumber nafkah hidup atau bahkan hanya untuk mencari tambahan sumber ekonomi. Pelibatan masyarakat ini juga sekaligus menjaga kelangsungan ekowisata dengan selalu ada wisatawan yang berkunjung.

Beberapa aktifitas harian nelayan dapat dijadikan sebagai kegiatan di Ekowisata MSB ini. Kegiatan ini akan memberi peluang ekonomi bagi nelayan melalui penghasilan langsung sebagai nelayan dan sekaligus sebagai penyedia jasa pendamping bagi wisatawan yang ingin beraktivitas sebagai nelayan. Terdapat 7 aktivitas nelayan yang terhubung langsung dengan mangrove sebagai kearifan lokal Kampung Kayu Ara Permai, sebagai berikut. 


\subsubsection{Ngaco (Memancing)}

Ngaco adalah istilah lokal untuk memancing dengan menggunakan joran dari bambu dan jarak dari benang umpan dengan ujung joran tadi tidak terlalu jauh, setelah itu cara menggunakannya dengan cara ujung joran dimasukkan ke air lalu air, lalu dikacau-kacau dengan menggunakan ujung joran. Airnya dikacau untuk menarik perhatian ikan agar memakan umpan. Umpannya bisa cacing biasa atau pumpun (cacing laut) yang biasanya hidup di batang - batang yang tumbang.

\subsubsection{Menanjow}

Menanjow sering juga disebut tajow yaitu memancing dengan menggunakan joran bambu yang ditancapkan ke tanah dan dibiarkan sampai ada ikan yang makan, biasanya orang menanjow tadi dengan jumlah yang sangat banyak, kadang sampai puluhan tajow sampai ada yang ratusan. Umpannya cacing biasa atau dengan pumpun.

Gambar 3. Aktifitas Masyarakat

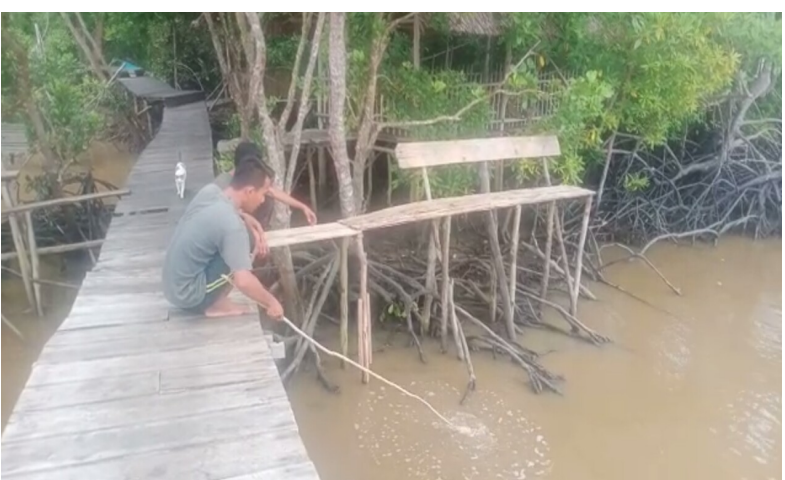

Aktifitas Ngaco

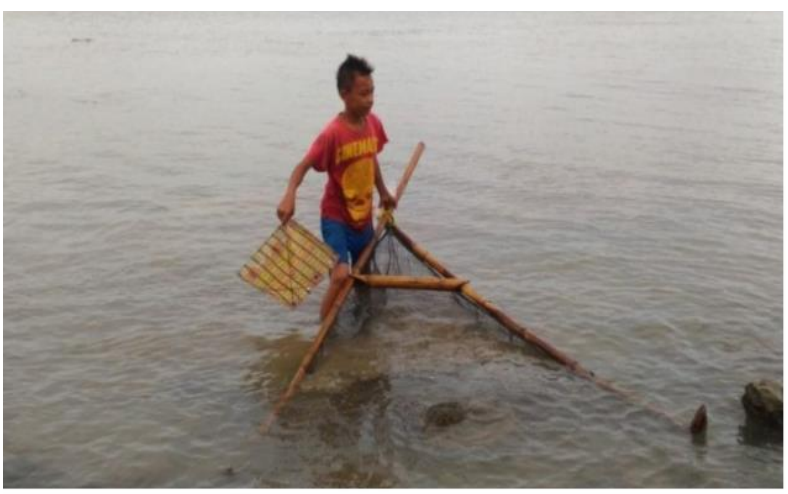

Aktifitas Menyondong

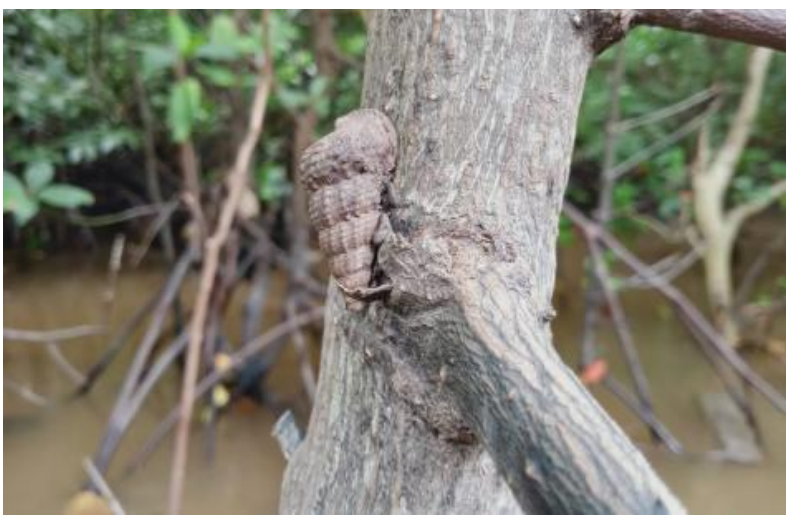

Siput

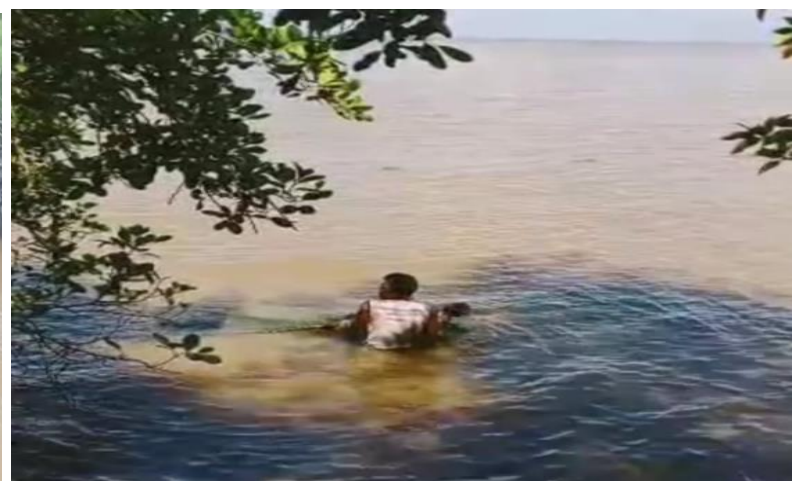

Aktifitas Kiso

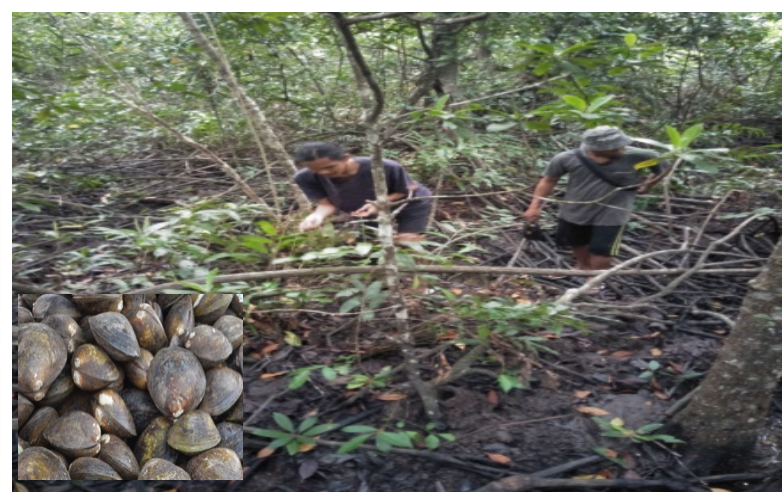

Aktifitas Mencari Lokan

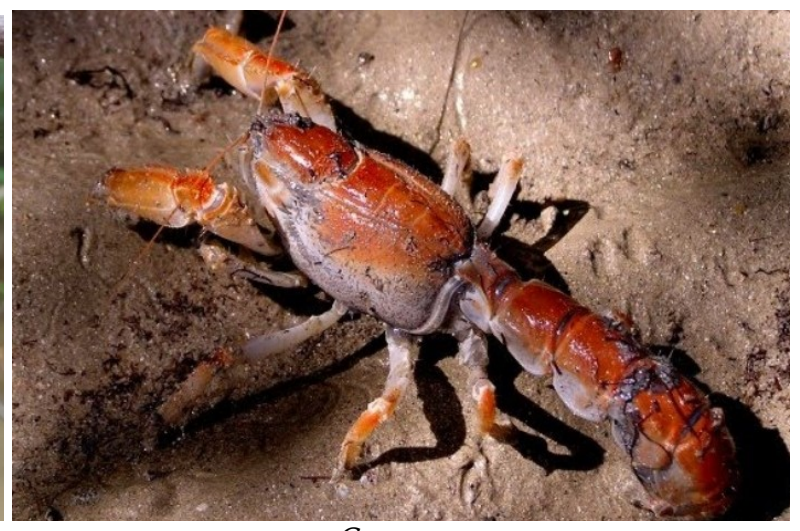

Gegano

Sumber: Foto Peneliti, 2021 


\subsubsection{Menudu}

Menggunakan joran pendek yang ditancap dipantai dengan umpan cacing / pumpun dan apabila sudah ada udang yang makan lalu di sauk menggunakan penyauk.

\subsubsection{Kiso}

Kiso aktifitas menggunakan jaring yang dipegang oleh dua orang yang satu di tepi pantai dan yang satu lagi berada di tengah laut dengan cara kedua orang tersebut memegang 2 ujung dari jaring tadi lalu menarik jaring tadi secara melingkar hingga 1 orang yang berada di tengah pantai tadi sampai di bibir pantai.

\subsubsection{Sondong}

Sondong adalah bambu yang disilang dengan menggunakan jaring yang didorong di pinggirpinggir pantai saat air surut. Ujung dari sondong tadi biasanya dipakaikan sabut niau (kelapa) atau sandal agar bambu tadi dapat dengan mudah menyisir pantai dan tidak tertancap ke tanah.

\subsubsection{Lokan}

Biasanya masyarakat mencari lokan di daerah ekowisata tapi para masyarakat setuju untuk tidak mencari lokan di daerah itu dulu selama setahun guna mendukung rencana pelaksanaan event berupa pencarian lokan. Even tersebut melibatkan semua masyarakat baik pengunjung atau yang sedang berada dilokasi. Bagi peserta perlombaan yang mendapat lokan paling besar, lokan paling banyak, orang yang pertama menemukan lokan diberi hadiah.

\subsubsection{Siput dan Gegamo}

Beberapa masyarakat masih sering mencari siput dan juga mencari gegamo (berupa kepiting tapi berukuran kecil yang hidup di tanah sekitaran mangrove). Biasanya gegamo muncul atau keluar dari tanah pada saat badai petir dan hujan lebat dan pada saat itulah biasanya masyarakat mulai mencari.

\section{Kesimpulan}

Tulisan ini menyimpulkan bahwa dalam pengelolaan ekowisata mangrove sangat penting berbasis pada nilai-nilai lokal. Kearifan lokal Sanak sedagho pada ekowisata MSB mampu membangun kesadaran kolektif bahwa ekowisata MSB merupakan milik bersama, yang perlu dikembangkan secara bersama dan sama-sama bertahan dalam kondisi sulit (covid 19). Bahwa manajemen pengelolaan berbasis kearifan lokal juga mampu meningkatkan nilai kompetitif dengan ekowisata sejenis di kluster area yang sama. Ekowisata MSB ini akan semakin kuat, berkembang dan menjadi destinasi wisata nasional jika kearifan lokal menjadi andalannya dalam mengisi kegiatan wisata di Ekowisata MSB.

Temuan ini berkontribusi pada bidang antropologi ekonomi, yaitu manajemen berbasis pengetahuan lokal yang berbeda dengan teori manajemen kontemporer. Manfaat dari penelitian ini adalah memberi tempat kepada kearifan lokal dalam pengelolaan ekowisata. Selain itu, penelitian ini menyarakankan untuk diteliti lebih dalam lagi terutama pengelolaan sanak sedagho untuk melihat hubungan perkembangan ekowisa dengan kearifan lokal.

\section{Ucapan Terima Kasih}

Penulis ucapkan terima kasih kepada AAI Pengda Riau, SKK Migas Subagut dan Enegi Mega Persada (EMP) MalacaStrait yang sudah membantu pendanaan penelitian dan bimbingan selama penelitian dan penulisan artikel ini. Penelitian dan tulisan ini terlaksana atas program Kolaborassi SKK MIgas - KKKS dengan AAI Pengda Riau. 


\section{Konflik Kepentingan}

Penulis dengan ini menyatakan bahwa tidak adanya konflik kepentingan dalam penulisan artikel ini.

\section{Daftar Pustaka}

Basyari, lin W. (2014). Nilai-nilai Kearifan Lokal (Local Wisdom) Tradisi Memitu Pada Masyarakat Cirebon (Studi Masyarakat Desa Setupakok Kecamatan Mundu). Edunomic, 2(1), 47-56.

Firdaus, F., \& Tutri, R. (2017). Potensi Pengembangan Ekowisata Di Nagari Kotobaru, Kecamatan X Koto, Kabupaten Tanah Datar, Sumatera Barat. Jurnal Kawistara, 7(2), 115-206. https://doi.org/10.22146/kawistara.13570

Kamarusdiana. (2019). Studi Etnografi dalam Kerangka Masyarakat dan Budaya. SALAM: Jurnal Sosial \& Budaya Syar'i, 6(2), 113-128. https://doi.org/10.15408/sjsbs.v6i2.10975

Kordi K, M. G. H. (2012). Ekosistem Mangrove, Potensi Fungsi dan Pengelolaan. Bandar Lampung: Jakarta Rineka Cipta.

Liap, A. L., Masyhudzulhak, \& Saluy, A. B. (2019). Manajemen Keberlanjutan Ecotourism Hutan Mangrove. Prosiding Seminar Nasional Peningkatan Mutu Perguruan Tinggi, 129-134. Jakarta: Universitas Mercu Buana.

Maunati, Y. (2001). Komodifikasi Budaya Dayak Dalam Konteks Industri Pariwisata di Kalimantan Timur". Makalah dipresentasikan pada Simposiaum dan Lokakarya International II.

Mukhlisi. (2017). Pengembangan Ekowisata Mangrove Di Kampung Tanjung Batu, Kecamatan Pulau Derawan, Kabupaten Berau. Jurnal Manusia Dan Lingkungan, 24(1), 23-30. https://doi.org/10.22146/jml.22939

Prabandari, D., Avenzora, R., \& Sunarminto, T. (2018). Kearifan Lokal dalam Pengembangan Ekowisata di Kota Bogor. Media Konservasi, 23(3), 274-280.

Prasiasa, D. P. O. (2011). Wacana Kontemporer Pariwisata (Cet 1). Jakarta: Salemba Humanika.

Rahmanto, B. D. (2020). Peta Mangrove Nasional Dan Status Ekosistem Mangrove Di Indonesia disampaikan dalam webinar "Development Mangrove Monitoring Tools in Indonesia. Makalah Seminar. Jakarta.

Rahyono. F.X. (2009). Kearifan Budaya dalam Kata. In Wedatama Widyasastra. Depok: Wedatamawidyasastra.

Setyowati, S. (2006). Etnografi Sebagai Metode Pilihan dalam Penelitian Kualitatif di Keperawatan. Jurnal Keperawatan Indonesia, 10.1, 35-40.

Sibarani, R. (2015). Pembentukan Karakter Berbasis Kearifan Lokal. Jakarta Selatan: Asosiasi Tradisi Lisan.

Spradley, P. (2007). Metode Etnografi (Ed.2, Cet.). Yogyakarta: Tiara Wacana.

Sugiyono. (2012). Metode Penelitian Kuantitatif. Bandung: ALFABETA.

Sumar. (2021). Penanaman Mangrove Sebagai Upaya Pencegahan Abrasi Di Pesisir Pantai Sabang Ruk Desa Pembaharuan. Ikraith-Abdimas, 4(1), 126-130.

Syahrian, W., Zulkifli, \& Efriyeldi. (2018). Analisis Hubungan Kerapatan Mangrove Dengan Kelimpahan Gastropoda Di Desa Kayu Ara Permai Kecamatan Sungai Apit Kabupaten Siak Provinsi Riau. Jurnal Online Mahasiswa, Vol 5, 1-13.

Tuwo, A. (2011). Pengelolaan Ekowisata Pesisir dan Laut - Pendekatan Ekologi, Sosial Ekonomi, Kelembagaan dan Sarana Wilayah (Pertama). Surabaya: Brillian Internasional.

Umam, K., Sudiyarto, \& Winarno, S. T. (2015). Strategi Pengembangan Ekowisata Mangrove Wonorejo Surabaya. Jurnal Agraris, 1(1). https://doi.org/10.18196/agr.116

Wati, M. W. (2017). Strategi Pengelolaan Ekowisata Mangrove Wonorejo Berdasarkan Preferensi Stakeholder. Institut Teknologi Sepuluh Nopember.

Winarno. (2017). Interpretasi Ekowisata. Bandar Lampung: Pusaka Media.

Windarni, C., Setiawan, A., \& Rusita. (2018). Estimasi Karbon Tersimpan pada Hutan Mangrove di Desa Margasari Kecamatan Labuhan Maringgai Kabupaten Lampung Timur. Jurnal Sylva Lestari, 6(1), 6674. 